\title{
The Traditional Christian Family Model and the Legal Status of Women in Hungary (1867-1948)
}

\begin{abstract}
The role of women in society is characterized by their positions in their families, their economic status, their education, and their employment, along with the political rights they have and the appropriate enforcement of those rights. My research on the social situation of Hungarian women starts in the latter half of the $19^{\text {th }}$ century, when, as a result of civil reforms in 1867, women's rights began to progress. The objective of my research, which is summarised in the present paper, is the presentation of the status of women in the area of labour law. I wanted to find out whether the traditional family model survived the $19^{\text {th }}$ century in Hungary, despite the fact that the status of women changed in the labour market and obviously also in family relations. In my work, focusing on the examination of the legal status of women, I concentrated on typical female jobs in agriculture. The paper focuses on the study of the available documents about women's work in the Archives of Somogy. Likewise, the research enables us to review the contemporary and later literature. In Hungary, employment for women became more widespread after 1890. The legislation of the Austro-Hungarian Dual Monarchy is fairly illustrative of women's status in labour law of the time. We can find that reforms in female education brought results only towards the end of the examined period. Until then women's roles in society were determined by the traditional family model, by their limited access to education, and particularly by the lack of vocational training for them. In my study I tried to emphasize that labour rights of women were closely connected with their educational rights in the age of Dualism. The present paper also confirms that the ambitions of women's movements to improve women's situations were the only answer to the circumstances of the time.
\end{abstract}

Key words: women's rights, emancipation, education, women's work.

\section{Introductory remarks}

We cannot find any work that would summarize the legal status of women in the field of education and labour in the examined period. The available documents about the history of women are descriptive case studies and deal with the history of society. The field of 
marriage and matrimonial property law are already written. ${ }^{1}$ I examined those fields of women's rights, in which the Hungarian women's movements stood up for women's rights. These are education, labour law, and prostitution. I wanted to know, whether traditional morals and a traditional family model survived at the turn of the $19^{\text {th }}-20^{\text {th }}$ century. The other question that I chose to undertake was whether culture or religion determined the status of women in the family.

Somogy county has always been a typical agricultural area and its nature was not unique in Hungary. Between 1913 and 1925 only agricultural branches of industry were progressing. ${ }^{2}$ Most of the workers - even women - were employed in agriculture as daylabourers, servants, or seamstresses before 1894. Industrial development started only in the interwar period, and it was closely linked to agriculture, especially to the food processing industry. ${ }^{3}$ Owing to its physical nature female employment was not significant in this industry.

\section{Characteristics of the Hungarian women's movements}

International contacts played an important role in the women's struggle, especially in verifying that the socio-political upheaval among women in Hungary should take place along the lines of the models of the upheaval in other Western-European cultures. ${ }^{4}$ However, the Hungarian endeavours towards emancipation differed completely from the foreign examples.

From the $4^{\text {th }}$ Century some theologians explained the relationship between genders in a peculiar way. They stressed the dominant role of the male, that - in their opinion derives from the history of creation. In subsequent centuries, European legal literature and legal practice emphasized a subordinate status for women in the family. But we must emphasize that this interpretation of theology didn't come only from the Christian faith, but that it mixed readily with the legal traditions of the Germanic tribes. ${ }^{5}$ Though Hungarian legal literature stressed the personal and financial independence of married women in the $19^{\text {th }}$ century, the new interpretation of theology affected it, too.

1 E.Cs. Herger, A növételtöl az állami anyakönyvvezetőig. A magyar házassági köteléki jog és az európai modellek [From the Purchasing of Women to the State Registration. The Hungarian Marriage Law and the European Models], Budapest-Pécs 2006; idem, A hozomány szerepe a magyar házassági vagyonjog fejlödésében [Dowry in the Development of the Hungarian Matrimonial Property Law], "Jogtudományi Közlöny” 2016, Vol. 4, pp. 193-203.

2 F. Szili, Munkássors - munkásgond Somogyban 1870-1945 [The Lives and Difficulties of Workers in Somogy 1870-1945], Kaposvár 1977, pp. 1-17.

3 K.T. Mérey, A gyáripar Somogy megyében a két világháború között [Manufacturing Industry in Somogy in the Interwar Period], "Somogy megye múltjából. Levéltári évkönyv" 1972, Vol. 3, p. 219 and p. 227.

4 S. Zimmermann, Die bessere Hälfte? Frauenbewegungen und Frauenbestrebungen in Ungarn der Habsburgermonarchie 1848-1918, Vienna-Budapest 1999, pp. 9-17.

5 E.Cs. Herger, A nö házassági vagyonjogi állása a német természetjogi kódexekben [The Status of Women in the Field of Marital Property Law in German Natural Law codes], "Acta Universitatis Szegediensis: Acta Juridica et Politica” 2016, Vol. 1 (in press). 
In Hungary, the efforts towards achieving equality overlooked the destructive nature inherent in family law. In contrast to Western-European countries, civil reforms were carried out mostly by the gentried class, as our society lacked a strong urban bourgeoisie. As the representatives of the early Hungarian women's movements, and especially those in literature, came mostly from the intellectual middle class, some authors consider it as one of the mistakes of the trend, that it examined only the cultural status of intellectual women. ${ }^{6}$ As we can see, women's movements in the $19^{\text {th }}$ century aimed at ensuring a fair place for women in the new market of manpower. It is also important to note that early movements did not demand civil rights and especially did not demand equal rights with men.

In Hungary, in the last decades of the $18^{\text {th }}$ Century, the importance of women's education was a political question. The politicians held that the key to the creation of the nation's integrity was the spreading of Hungarian culture widely, consequently women's education was supported..$^{7}$ Important results of this period were the development of women's individualism and the drawing up of some important demands of fundamental human rights for women.

The Hungarian legal system - in contrast with that of Western-Europe - ensured privileges and personal and financial independence for married women before 1848. In general, a noble married woman did not depend on her husband in representing her own rights. Moreover, she was allowed to represent her husband in court in some actions. ${ }^{8}$ So before 1848, Hungarian married women had extensive rights in private law. ${ }^{9}$

Although the press of the 1848/49 Revolution and War of Independence carried on emphasizing women's role as men's partners in the fight for the nation's sovereignty, Act V of 1848 concerning the election of Members of the Hungarian Parliament (hereinafter: Act V of 1848) definitively excluded women from suffrage (2. §). Moreover, as new statutes cancelled feudal privileges, widows of the mass classes were deprived of their former indirect political right to have themselves represented in parliamentary and municipal sessions by emissaries. This new regulation was not unique. For example, in 1787 the Constitution of the United States of America superseded and thereby nullified women's right to vote in those states where it had previously been granted. The French Revolution extended the scope of the principle of equality before the law to women. However, after 1793 women's political activities were specifically restricted. ${ }^{10}$

But Hungarian women remained realistic in 1848, they deliberately refrained from pressing their cause beyond their power to achieve their goals. However, the practical realization of women's emancipation in Hungary was stifled after the suppression of

6 F. Baráth, Nevelés, tudomány, nöügy. A nők munkaköre [Education, Science, and Women's Affairs. Women's Jobs], Budapest 1872-1873.

7 Á.H. Pálóczi, A magyar asszonyok prókátora a Budán összegyült rendekhez 1790 II [The Representative of Hungarian Women to the Assembled Estates in Buda 1790 II], Budapest 1822, p. 70.

8 F. Cserei, A magyar és székely asszonyok törvénye [The Act Concerning Hungarian and the Székely $<$ i.e. Magyar of Eastern Transylvania> Women], Kolozsvár 1800, p. 12.

9 A. Máday, A magyar nö jogai a múltban és a jelenben [Rights of the Hungarian Woman in the Past and in the Present ], Budapest 1913, p. 37.

10 A. Fábri, A nö és hivatása II. Szemelvények a magyarországi nőkérdés történetéből 1866-1895 [The Woman and Her Profession II, Selected Passages from the History of the Hungarian Women's Question 1866-1895], Budapest 2006, pp. 215-216. 
the Hungarian Revolution and War of Independence. During the era of absolutism the "woman question" was neglected and came to the forefront again only after $1867 .{ }^{11}$

\section{Special demands of the individual stages of the movements in Hungary}

Based on the Hungarian characteristics of historical development, legal historians distinguish four stages of the movement: from the beginning until 1896, from 1896 until 1904, from 1904 until 1918, and from 1919 until 1945. ${ }^{12}$

By the 1850's, the social status of women did not meet the actual requirements of the era, where the number of marriages dropped more and more, and where women were forced increasingly to be the principal breadwinners for their families. ${ }^{13}$ However, almost nobody supported women's emancipation, and institutions of higher education for women were still absent. ${ }^{14}$ Organized activities started after 1861, when the Association of Hungarian Housewives was founded. Only a few years later, on the $24^{\text {th }}$ of May in 1867 Mrs. Paul Veres and a few determined women formed the Association of Women's Education. From this point on, Hungarian women also started fighting for the expansion of their rights in organized forms. ${ }^{15}$ Mrs. Veres believed that the scientific education of women was the most important precondition for emancipation, and encouraged other women to stand up for the education of their children through the age of 18 or 19. She is noted for the establishment of the first girls' high school which became a significant educational institution at the secondary level. Her historical merit was that by encouraging women's active participation in the actions taken in their interest, she made the women's emancipation movement - namely the educational rights and existential interests of women - a broader social issue. ${ }^{16}$

The movement achieved results only after 1867, when the changed economic environment brought along the need for a change in women's social status. The existence of single women who belonged to the gentry or middle and lower or intellectual classes, had also created a social problem previously, as there were no proper jobs suitable to their social status. By the 1860 's this problem, which was closely connected to the lack of women's professional education - became almost irresolvable. ${ }^{17}$

11 B.Gr. Teleki, Elöbb reform, azután Nöemanzipátió [First Reform then Emancipation], "Életképek" 1848, Vol. 4, p. 593.

12 J. Szapor, A magánszférából a politikai közéletbe: a nöi politizálás története a kezdetektöl 1945-ig [From Private Sphere into the Political Public Life] [in:] M. Palasik (ed.), A nö és a politikum [The Woman and Politics], Budapest 2007, pp. 130-131.

13 E. Kánya, A háború és a nök [War and Women], "Családi Kör" 1866, p. 482.

14 A. Fábri, $A$ nö és hivatása II..., pp. 237-314.

15 P.E. Illés, Az amerikai nők gyülése [Assembly of the American Women] [in:] A. Fábri, A nö és hivatása II..., pp. 286-290.

16 H.V. Beniczky, Felhivás a nökhöz [An Appeal to Women], Hon 1865.

17 A. Fábri, $A$ nö és hivatása II..., pp. 185-243. 


\section{Objectives of the Hungarian movements}

\subsection{Marriage obligation and property law}

The emancipation of women could only start after the Austro-Hungarian Compromise of 1867, when civil reforms were carried out. It is important to note that women's struggles should be particularly valued among the characteristics of the Habsburg Monarchy. In this society relations between men and women were based on the traditional family model.

The private capacity of women was extended under Act XXIII of 1874 concerning women's right to majority. According to 1 . $\S$ of the Act, the age of majority for singles was 24 years, when they obtained full rights of majority. There was one exception to this rule, namely single women who married - regardless of their age - and attained majority by virtue of the marriage. They were entitled to keep this privilege the above menthoned even if they were widowed, separated from their husband based on a court's decision (Divorce a Mensa et Thoro), or their marriage was dissolved by a court. The importance of this rule lies in the fact that the statute did not contain the same rule for men.

The situation was not as good in the field of marriage obligation law. ${ }^{18}$ In Hungary, the modernization of marriage laws took place only in 1894 and the results were not perfect in all areas of gender equality, neither in Act XXXI of 1894 of Hungarian marriage law (hereinafter: Act XXXI of 1894) which introduced obligatory civil marriage, nor in legal practice. ${ }^{19}$

\subsection{Demands in social care}

Legal regulations related to maternity protection are determinate factors of women's status in family and society. Women had long been fighting for allowances in connection with childbirth and other social services, since women were not entitled to paid maternity leave or any other financial support until 1891. Before 1928, women did not get old age pensions or widow's allowances, and had no orphan's or disability insurance. Beyond this, the amount of unemployment benefits was less than men's. ${ }^{20} \mathrm{By}$ the turn of the $19-20^{\text {th }}$ century actual government policies strove to insert the above-mentioned benefits into the health insurance system in order to reduce the high infant mortality rate. $^{21}$

18 S. Zimmermann, Die bessere..., pp. 389-400.

19 E.Cs. Herger, A növételtöl..., pp. 127-128.

20 E. Bassa, Mit kell tudni a nömozgalmakról [What Must be Known about the Hungarian Women's movements], Budapest 1982, pp. 38-39.

21 K.N. Szegvári, Út a nők egyenjogúságához [The Way to Emancipation], Budapest 1981, pp. 116-121. 


\subsection{Demands in education}

In the field of education rights, the results that Hungarian women obtained in 1868 had already been reached by their French compatriots in 1789 . In other words, $20 \%$ of them were able to read and write. In our educational system the training of women and girls was long separated institutionally, which resulted in diminished educational rights. ${ }^{22}$

Until 1865, when Mrs. Paul Veres founded her institute, the only secondary level educational institution for women was the "Institute of English Ladies", which was founded in 1856 in Pest, and was the only institute that prepared women for breadwinner jobs. ${ }^{23}$ While elsewhere in Europe women could study at different faculties of universities in prior decades, in Hungary, they had to wait until 1895 to achieve the right to equivalent educational opportunities. The contemporary public opinion regarded women as being suitable mostly for pedagogical and medical professions. And even so, their male colleagues rarely welcomed them sympathetically. ${ }^{24}$

We are going to see that rights acquired in higher education were limited again after the First World War by the order called "numerus clausus" (Act XXV of 1920 of the rules of registration at universities, Polytechnic, Faculty of Economics of the University of Budapest, and at the Academy of Law). At first, the law limited only the educational rights of women, but later also those of Jewish students. So some university faculties were opened to them only after the Second World War.

As we have already seen, it wasn't until the 1860's that Hungarian activists in the women's movement realized that they should start the fight in the field of education. At the time, they did not aspire to anything more than having equal educational rights to men. However radical changes in institutional education for women didn't show up until the timeframe between 1867 and 1895 when state politics became more liberal.

\subsection{Women's struggle for labour rights}

Even as the old ones remained, women met new forms of sexual discrimination. A good example of this was the case of Karolina Ember (Mrs. György Illyés) in 1870. She was the first skilled Hungarian female shorthand writer who applied for a job in Parliament. In spite of her undisputed skills, the President of the House, Paul Somssich, did not permit her employment because of her gender, although the legislative body had previously accepted her application for the job. She did not get the job, but this case was a very important leap forward in emancipation in the field of labour rights, since the majority of the members of the parliament - who were men - voted in favour of her application. ${ }^{25}$ Also radical changes were needed in the field of working conditions. ${ }^{26}$

22 S. Zimmermann, Die bessere..., pp. 391-392.

23 K.N. Szegvári, Út a..., pp. 92-95.

24 J. Kovács, Utazás a nöi egyenjogúság körül [Travelling around Emancipation] [in:] E. Bassa, Mit kell..., p. 45.

25 A. Fábri, A nö és hivatása I..., p. 186.

26 K.N. Szegvári, Út a ..., pp. 116-121. 


\subsection{Public appearance and political rights}

Few classical civil revolutions included the emancipation of women among their goals; they actually failed conspicuously in this area. ${ }^{27}$ Regarding political rights, we can declare that Hungarian women of the nobility enjoyed more rights before 1848, than they did afterwards when the laws of April that were passed by the Hungarian Parliament in 1847-1848 and were approved by King Ferdinand V deprived them of some previously held privileges. For example, in feudal society widows were entitled to hold political offices in certain cases, such as the position of the lord lieutenant, based on nomination, or before 1848 the so called "boyish" women and widows residing on their husband's land could be appointed president of the manor-court or could attend sessions of local authorities or Parliament through their representatives. ${ }^{28}$

However, by stating that "the woman" is not eligible to vote, Act V of 1848 eliminated the earlier indirect voting rights of noble women. Although legal authors of this age pressed for the abolition of certain forms of gender discrimination in private law, at the same time they were against the granting of broader political rights to women. All the laws about voting rights of the $19^{\text {th }}$ Century excluded women from suffrage (Act V of 1848, Act XXXIII of 1874, and Act XIV of 1913 concerning the election of Hungarian Members of Parliament). ${ }^{29}$

In spite of the early results of the civil era and the Hungarian Soviet Republic, we can see regression in political rights for women after $1919 .{ }^{30}$ The order that modified voting rights after 1919 reduced the number of women who were able to vote by 570,000 $(40 \%)$. In the interwar period women's voting rights were still more limited than men's. General and universal suffrage was implemented only in 1945 after the Second World War. ${ }^{31}$

\subsection{Issues in criminal law, the matter of prostitution}

If we want to promote women's status in society we cannot set aside the discussion of the subject of prostitution. In the $18^{\text {th }}$ Century people began to realize that venereal diseases had a negative effect the health of military personnel. The Empress Maria Theresa closed down all the brothels in Austria in 1765. Thanks to this, large numbers of prostitutes were deported to Hungary. Joseph II ordered the rounding up of prostitutes in 1782 and placed them in detention centres. The number of prostitutes increased significantly in the second part of the $19^{\text {th }}$ century. In spite of the prohibitions implemented by regulations

27 H. Ruth, H. Simon, Women and Political Power: Europe since 1945, London-New York 2000, p. 16.

28 K. Csiky, A magyar nö jogai [Rights of Hungarian Women], Nemzeti Nönevelés 1894, p. 121.

29 E. Bassa, Mit kell..., p. 41.

30 M. Palasik, A nö..., pp. 227-257.

31 CS. Lehoczky Kollonai, Amerikai sikertörténet - európai változások. A női egyenjogúság a nemzetközi gyakorlatban [American Success Story - European Changes. Women's Emancipation in International Practice] [in:] A hátrányos megkülönböztetés tilalmától a pozitiv diszkriminációig. A jog lehetösége és korlátai [From Prohibition of Discrimination to Positive Discrimination. The Opportunities and Limits of the Law], Budapest 1998. 
early in the $19^{\text {th }}$ century, by the end of the century, a whole prostitution industry had developed. After 1815, Pest became the centre of white slave traffic.

If we search for reasons behind prostitution, we can find personal, family, and social causes. According to social scientists, among individual causes the most significant is men's demand, and the most mentioned social reason is women's poverty. Most of the prostitutes had poverty problems and came from working-class families, or were unemployed servants, working women, or lonely pregnant girls. Although some social benefits were available to the poor at that time, they were insufficient to help these women's dire situation, as women and girls who belonged to the lowest classes of society were completely excluded from these modern measures because they were categorized as "morally fallen." 32

The key issue of regulation concerning prostitution was the prevention of diseases. The first regulation of brothels appeared in 1867 in the capital (the Statute of 1867 on the regulation of prostitution, brothels and prostitutes, hereinafter: Statute of 1867), which became a model. The aim of the regulation was to draw up the frameworks of prostitution. ${ }^{33}$ However, the new order could not completely fulfil the purpose for which it was created, because it could not prevent the so-called "secret prostitution".

A new order came into force in 1884: the statute of the case of brothels. In this timeframe, the legislature recognized the broad extent of secret prostitution and took stern measures against secret prostitutes, while largely disregarding the phenomenon of "private harlots." After 1884, the number of brothels dropped significantly, while an increasing number of prostitutes continued to work as private harlots. Working as a harlot gave women greater control over their own fate. The place of work also changed, as hotels, clubs, and cafes became the harlots' functional areas. At the turn of the Century, a new rule appeared. Legislation focused rather on prevention than on police control. It was hard for the society to recognize that not only prostitutes spread venereal diseases.

In 1909, a new statute [Statute 881-1008/1907 on prostitution] came into force. One of the main provisions of this statute took measures against prostitutes. This regulation had already been formulated in the Statute of 1867, due to the efforts of the women's movements. From 1911 women activists could visit harlots who were under medical treatment in hospitals and try to dissuade them from continuing the practice of this profession.

Under the new rules which were formulated in the above mentioned statute, prostitutes were supposed to have medical examinations and could get health cards if they did not suffer from any venereal diseases. But they could still work secretly outside the provisions of the law. The main result of this regulation was that from that time on women who worked as prostitutes were officially screened for prevention of venereal diseases.

There is no doubt that white slave trade was the most dangerous crime among those linked with prostitution. Until 1908, there were no sanctions against this act at all in the Hungarian Criminal Code. The only legal proscription against it was a ministerial order

32 E. Schreibel, A prostitúció [Prostitution], Budapest 1917, p. 106.

33 J. Miklóssy, A budapesti prostitúció története [The History of Prostitution in Budapest], Budapest 1989, p. 37.

Artykuły - Articles 
from 1869 that classified this act as a petty offence. ${ }^{34}$ Harlots were excluded from the protection provided by criminal law even after the modification of the law in 1908, because according to the public opinion of the time, only honourable women could suffer injuries in a crime like the white slave trade, while in the case of harlots, there were no values to defend. ${ }^{35}$

In the $20^{\text {th }}$ Century, both women activists and the signatories to the International Convention on the prosecution of white slave traffic signed in Paris in 1910 were working hard to find a solution for this problem. The main objectives of the activists were the reduction of secret prostitution, the protection of harlots against exploitation, as well as the extension of medical control.

In 1912 a group of determined women started to work at the Police Headquarters in Budapest to dissuade applicants for registration from entering into this profession. That same year the Union of Hungarian Women's Associations suggested that the minimum age limit for registration be set at 18 years, but their aims were not realized in the examined period. ${ }^{36}$

Radical changes of the subject occurred only after the First World War. ${ }^{37}$ The actual political power did not previously make any real efforts to change the situation and it stayed the same until the end of the studied era. For example: in Hungary the penalty for committing public scandal - an offence that could be charged against secret harlots under existing laws - was a maximum of one month of imprisonment, while in Austria after 1885, harlots could be sentenced to three months in prison, or in certain cases even forced into penal servitude for committing the same act. We must not disregard the fact that with reference to social needs and to the expected significant tax-revenue from the owners of brothels authorities often disregarded the enforcement of the law.

\subsection{The ones left out of reforms}

Servants had the worst social position. The women's movements did not bring any changes in their status. They were totally deprived of civil rights until 1907. Once they were employed, they had to give up their freedom, and lived under the total control of their employers, to the extent that even their responsibility in criminal law was limited. Nor could they expect any unemployment benefits after the termination of the employment. ${ }^{38}$ Not until Act XLV of 1907 of the rules concerning legal relations between smallholders and servants (hereinafter Act XLV of 1907) was any provision made for compulsory benefits for childbirth and maternity, but internal (household) servants - the most of whom were women - were left out of even these benefits. This statute advanced

34 F. Finkey, A magyar büntetőjog tankönyve [Coursebook of Hungarian Criminal Law] [in:] B. Mezey, Magyar jogtörténet [Hungarian Legal History], Budapest 1996, pp. 287-288.

35 B. Récsei, A kéjelgésügy szabályozása Somogy vármegyében a dualizmus második felében [Regulation of prostitution in Somogy County in the Second Part of the Dualism Era], "Somogy megye múltjából. Levéltári évkönyv" 2001, Vol. 32, p. 193.

36 E. Schreibel, A prostitúció..., p. 72.

37 J. Miklóssy, A budapesti..., p. 89.

38 A. Fábri, A nő és hivatása I..., pp. 185-243. 
rights only for external (economic) servants, as they had the right to a safe job, a healthy residence, maternity benefits, free medical care, and an old age pension. ${ }^{39}$

\section{Educational rights of women in the era of the Austro- Hungarian Dual Monarchy}

In 1869 only $20 \%$ of women in Somogy could read and write. ${ }^{40}$ We can estimate that the $80 \%$ of illiterate women belonged to the lower social classes. After the AustroHungarian Compromise of Constitutional Law (1867) that created the Austro-Hungarian Dual Monarchy, the 1868 law on public school education aimed at the realization of civil reforms in the field of education (Act XXXVIII of 1868 about Public primary education, hereinafter referred to as "PE"). This law could induce essential results in women's education but only in the field of public primary education.

The main result of this reform was the reduction of illiteracy. The reasons for these limited results can be found in professional training and in secondary education. At the beginning vocational training was totally non-existent for women, and there were only two institutions of secondary education that women could attend: the teacher-training college and the bourgeois girls' school newly established by the PE.

If the objectives of the $\mathrm{PE}$ had been attainable in practice, primary education of women would have changed radically. In my study I am going to present the circumstances that prevented the practical materialisation of these objectives in Somogy, both in terms of the teaching material to be conveyed, and the bi-level education system purposed by the Act. The preponderance of denominational schools had numerous consequences that I present below. ${ }^{41}$

Besides the traditional family model that determined social relations, we can find many marks of indifference towards education in Somogy according to official statements of local authorities, based on the correspondence of local tribunals, municipalities, and royal school inspectors. ${ }^{42}$ There were villages where the new law was unheard of even 2 years after its introduction. Social and economic circumstances at the time, such as attitudes of parents, labour requirements in agriculture, lack of infrastructure, and the predominance of denominational schools also obstructed the implementation of the reforms. Statistical data demonstrating the percentage of those attending schools covered only winter months, when, however, the lack of adequate clothing and footwear often prevented children from going to school. During agricultural working seasons children

39 G. Jánossy, A feminizmus Magyarországon [Feminism in Hungary], Szombathel 1911, pp. 31-140.

40 K.N. Szegvári, Az 1868. évi XXXVIII. tc. jelentösége a nöképzés szempontjából [The Role of the Act XXXVIII of 1868 Concerning Women's Education] [in:] A. Csizmadia (ed.), Jogtörténeti tanulmányok I., Budapest 1966, pp. 55-72.

41 E. Kelemen, Adatok a népoktatás Somogy megyei történetéhez (1881-1918) [Data on the History of Public Elementary Education in Somogy (1881-1918)], "Somogy megye múltjából. Levéltári évkönyv" 1980, Vol. 11, pp. 329-334.

42 E. Kelemen, A népoktatás Somogyban a kiegyezés elötti években [Public Elementary Education in Somogy before the Compromise of 1867], "Somogy megye múltjából” 1972, Vol. 3, pp. 137-168. 
over the age of 10 were withheld from going to school, because they had to work. As the majority of the population in Somogy was working in agriculture, a compromise solution was found in February, 1868, when - taking parents' interests into account - the school year was shortened to only six months for children between the age of 10 and 12 years. ${ }^{43}$

The goals of the PE were to introduce general and compulsory education for the age group between 6-12 years and to provide the same teaching material for both sexes. In practice these aims could not be realized in Somogy. For one thing, teachers were not skilled enough, and beyond this the teaching material differed in denominational schools, as the law did not require them to teach all subjects that were compulsory in public schools, which caused the low standard of local education. Small denominational schools with only one teacher were widespread in Somogy, and the rate of municipal and denominational schools hardly changed in the examined period. ${ }^{44}$

According to the PE, public elementary education included two major units: everyday education lasting 6 years and repeteur education for 3 years. It meant that even those who didn't want to attend any upper public schools couldn't finish their studies, because children over the age of 12 and those who finished the 6 years of everyday school, had to attend the so-called repeteur school. ${ }^{45}$ According to the royal school inspector's report of 1872 there were no repeteur schools in Somogy meeting the requirements provided by PE, and after 1872 the institution wasn't even mentioned in the royal school inspector's reports anymore. ${ }^{46}$

The PE provided that municipalities with more than 5000 inhabitants shall establish upper public schools, or if they can afford it, they shall establish and maintain the socalled bourgois girls' schools. ${ }^{47}$ The Programme of girls' school gave general knowledge, but it was built on traditional female roles. Although the PE contained rules that discriminated against women, such institutions did not exist in Somogy between 1867 and 1870 at all. ${ }^{48}$ The provisions of the PE concerning upper public schools made a $d i$ rect differentiation between the education of boys and girls, both in terms of the training period and the teaching material. The lack of this institution in Somogy in the examined era proves that that absence of vocational training of women is closely linked to the traditional understanding of what constituted female occupation. ${ }^{49}$

According to the PE major municipalities that could afford it, were required to establish bourgeois schools instead of upper public schools. These bourgeois schools separated male and female students and made no distinction between them based on religion. ${ }^{50}$ But the Act and its implementing regulation contained no deadline for the implementa-

43 E. Kelemen, A népoktatás Somogyban a dualizmus kezdö éveiben (1867-1870) [Public Elementary Education in Somogy at the Very Beginning of Dualism (1867-1870)], "Somogy megye múltjából” 1973, Vol. 4, pp. 205-206.

${ }^{44}$ Királyi tanfelügyelöi jelentés [Report of the Royal School Inspector], "Somogy” 1893, Vol. XXIX, p. 11.

45 Act XXXVIII of 1868 concerning public primary education 48. $\S$ and 50. $\S$.

46 "Somogy politikai és vegyes tartalmú hetilap" [Somogy Weekly Paper of Political and News Item] 1873, Vol. 20.

47 Act XXXVIII of 186859 ..

48 "Somogy" 1873, Vol. 20.

49 "Iskolai szemle" 1890, Vol. X, p. 2.

50 Act XXXVIII of 1868 67. $\S$ and 71.. 
tion. ${ }^{51}$ The first bourgeois girls' school was established only in 1882 in Kaposvár with the help of a state subsidy. ${ }^{52}$ Subsequently several privately and community-maintained bourgeois girls' and boys' schools were established throughout the county, but the common status of their buildings was bad, although the standard of education proved to be sufficient due to the commitment of teachers. ${ }^{53}$

The school syllabus of the girls' school served traditional female educational purposes. It covered only a small number of women and it only sought to give them a general education. ${ }^{54}$ The existing school system did not want to advance women's participation in further learning, they could not even take a final examinations. ${ }^{55}$

Act XXX of 1883 concerning grammar schools settled the admission requirements for secondary schools, making it possible for girls who had attended a girls' school or an upper public school to be admitted to a secondary school as private pupils. ${ }^{56}$ In my opinion the only girls who had the chance to gain admission were those who could previously acquire the skills and knowledge required as private students. In Kaposvár, the first grammar school for girls was established at the very end of this period, in $1918 .{ }^{57}$

After finishing the bourgeois girls' school, women could work as low level officials, as governesses, or as teachers. After 1889 some of them could attend upper secondary schools or female trade schools (established in 1891 in Kaposvár), or after the $4^{\text {th }}$ class of the bourgeois girls' school they could enter into the $5^{\text {th }}$ class of a grammar school, but only after passing a demanding entrance examination. ${ }^{58}$

For a long time, teaching was the only intellectual profession for women in Somogy. ${ }^{59}$ It is important to note, that one of the 5 teacher-training colleges established in the 1860's in Hungary opened in the village of Csurgó in Somogy County. At that time school-policy discriminated against female teachers and relied on their lower expectations, i.e. women's wages were much lower than men's. ${ }^{60}$

The new school system brought chaos to the field of female education. The teaching staff could not understand the difference between the three types of girls' schools, namely the upper public girls' school, the so-called bourgeois girls' school, and the grammar school for girls. Ultimately, the conditions provided by the PE were only implemented

51 B. Tobak, Nönevelésünk jelen állapota [Actual Status of our Women's Education], "Somogy” 1869, Vol. V, p. 4 and p. 2.

52 Csákányi, Polgári leányiskola [Bourgeois Girls' School], "Somogy” 1882, Vol. XVIII, pp. 1-2.

$53 \mathrm{Kgb}$. iratok [Documents of the Administrative Committee], "Somogy Megyei Levéltár" 1905, Vol. 184, 99/1913, 265/1914, 81/1915, 33/1916, 38/1918.

54 K.N. Szegvári, $A z 1868 \ldots$, p. 62.

55 Tanterv a polgári iskolák számára az 1868-dik évi XXXVIII. tcz. értelmében [School Syllabus for the Bourgeois Schools in Terms of Act XXXVIII of 1868], Néptanítók Lapja 1869 [in:] K.N. Szegvári, $A z$ $1868 \ldots$, pp. 62-65.

56 A vallás és közoktatásügyi miniszter 72.039 (XII.31.) sz. rendelete [Order of the Minister of Religion and Public Education, vol. 72.039] [in:] M.N. Csorba, A Kaposvári Államilag Segélyezett Községi Polgári Leányiskola Értesitöje az 1896-97. tanévröl [School Report of the Communal State-Supported Bourgeois Girls' School of Kaposvár from the 1896-97 School Year], "Somogy Megyei Levéltár, Kaposvár" 1897, pp. 52-70.

57 E. Kelemen, Kaposvári dualizmuskori közoktatástörténetének vázlata [Summary of the History of Public School Education in Kaposvár in the Age of Dualism], “Somogy” 1973, Vol. 3, pp. 121-125.

58 J. Csorba, Értesítö 1896-97..., pp. 64-70.

59 B. Tobak, Nönevelésünk..., p. 2.

60 K.N. Szegvári, Az $1868 \ldots$, p. 67. 
by the turn of the $20^{\text {th }}$ century, and even then, not completely. As the rate of the nativespeaker population was above $82 \%$ in the county in 1850 , no larger state subsidies could have been expected for the realization of the national education policy. ${ }^{61} \mathrm{By}$ the end of the examined period the number of public primary schools increased by $20 \%$. The two institutions that I mentioned above - namely the bourgeois girls' school and the teachers' training school - represented a major step forward, because in the former educational system only the children of wealthy families could carry on with their studies after primary school. The education of the rest of the women pupils - who constituted the majority - consisted of attending seamstress courses. By the end of the era of Dualism, women's demand for state secondary education became obvious. ${ }^{62}$

\section{Regulation of the employment of females individually in Somogy county}

\subsection{Servants and agricultural workers}

Due to the system of landlordism, the number of agricultural workers in Somogy was high. Estates bigger than 100 Hungarian acres of land took up 70,43\% of the county's land area. In the $19^{\text {th }}$ century seasonal agricultural workers showed up in Somogy. ${ }^{63}$ In $1870,91 \%$ of the population pursuing any professional or trade activity worked in agriculture and only $8 \%$ were employed in industry. ${ }^{64}$ By 1891 the number of farmers decreased to only $69 \%$, and $13 \%$ made their livings as day-labourers.

The present paper is based on legal cases involving servants in Somogy. There can be no doubt, that women did most of the domestic works, so most of the so-called inner (domestic) servants were women.

In Hungary, a standard regulation concerning servants did not exist before the end of the $19^{\text {th }}$ century. Unwritten law had dominated for a long time. In 1876 the first law concerning servants came into force (Act XIII of 1876 concerning legal relations between smallholders and servants, hereinafter the Act XIII of 1876). The legislature tried to bind servants and it did not defend their dignity. The humiliation of servants by their landlords had been a common practice, and now it was actually codified in law. ${ }^{65}$ According to analytical studies the Act was suitable for resolving the problems neither legally, nor socially. ${ }^{66}$ This act was the single law of the examined period that regulated the legal rela-

61 J. Csorba, Somogy vármegye ismertetése [Introduction to Somogy County], Pest 1857, p. 14.

62 K.N. Szegvári, $A z 1868 \ldots$, p. 65.

63 K. Baross, Magyarország földbirtokosai és bérlői [Landowners and Tenants of Hungary] [in:] K.T. Mérey, Adatok a déldunántúli uradalmak gazdasági cselédségének életviszonyaihoz a századforduló idején [Data on the Living Conditions of Agricultural Servants of the Estates of South-Transdanubia at the Turn of the $20^{\text {th }}$ Century], Pécs 1957 , pp. 3-20.

${ }^{64}$ K.T. Mérey, A gazdasági és társadalmi viszonyok fejlödése Somogy megyében 1870-1918 [Progress of Economic and Social Relations in Somogy County 1870-1918], Kaposvár 1973, p. 26.

65 Act XIII of $187645-46 . \S$.

66 V. Sápi, A mezőgazdasági cselédség magánjogi helyzete a dualizmus korában [Legal Status of Agricultural Workers in Private Law in the Age of Dualism] [in:] Jogtörténeti tanulmányok II. A dualizmus korának állam- és jogtörténeti kérdései, Budapest 1968, pp. 300-302. 
tionships of domestic servants with their employers. Female servants are mentioned only in two paragraphs of the Act, which shows the traditional interpretation of law. A good example of the lack of protection for female workers is that the law enabled the landlord to legally terminate the contract with the worker before the term of notice if the female servant became pregnant. ${ }^{67}$ In 1898 a new law came into force, which re-regulated the legal relations of agricultural workers and day-labourers. However, the law did not contain any provisions about female servants.

Act XLV of 1907 determined legal relations between lords and servants until the end of the period. The only positive change brought by this Act was that it prohibited forced labour. However, any legal rights for servants were fictitious, since their enforcement depended on the lord's favour. ${ }^{68}$ The legislature once again forgot the issue of domestic servants. If statutory provisions were absent, the law provided for the usage of local custom.

Lords were legally obliged to pay the elementary school fees of the children of servants' who were employed throughout the year. At the same time they did not have to pay the school fees of domestic servants' children, because - as provided for by Act XIII of 1876 - lords only had to provide domestic servants' children the possibility to attend school. The above mentioned situation of public elementary education was closely connected with the living conditions of servants and with the agricultural nature of the county, since in this environment the level of children's education fell almost to that of medieval times, and the opportunity for and value of their schooling was also very low. ${ }^{69}$

The lowest-paid class of servants were domestic workers, and neither were they protected by legal guarantees - like the prohibition of child work introduced in 1907. Their working hours and duties were not regulated during the examined period. According to the rules of Somogy county of 1873, servants were permitted to attend Sunday church service only if housework was done. Domestic servants could not educate themselves, they did not have any other work possibilities, and they did not get any old-age allowance either. So, servants who were singles, could continue their service or worse, become prostitutes. This situation contributed to the high number of prostitutes both nationwide and locally. In the capital a third of the children born out of wedlock came from servants. Unfortunately, suicide was also very common among them.

In Somogy county, the first ordinance concerning servants was introduced in 1776 , and was first amended in 1873. The terms of the statute were imposed by the lords. This statute applied to domestic servants, too. Their miserable situation is apparent also from local regulation, which even provided that servants should not be ,picky” about their meals. $^{70}$

Afterwards, two ordinances came into force, which were based on Act XLV of 1907. Both of them concerned only agricultural workers. The first one regulated servants' em-

${ }^{67}$ Act XIII of 187651 . § I. f.

68 Gy. Rácz, A cselédtörvény javaslat birálata [Critique of the Proposal on the Servants' Act], Budapest 1909 [in:] Mérey, Adatok..., pp. 3-20.

${ }_{69}$ Mezei munkásság, házi cselédség [Agricultural Workers and Domestic Servants] [in:] Magyar Néprajz VIII. Társadalom, mek.niif.hu/02100/02152/html/08/98.html, pp. 1-6.

${ }_{70} \mathrm{Az}$ 1873. évi cselédrendtartás [Regulation of 1873 about Servants], Somogy Megyei Levéltár kiállítási anyaga [Exhibition Material of the Archives of Somogy]. 
ployment periods, the obligatory payment of their earned wages, and the order of the holding. ${ }^{71}$ The second ordinance, issued in 1908 regulated the housing of domestic servants. ${ }^{72}$ Although not all of its provisions were ever fully implemented, many new and healthy houses were built for servants in the county pursuant to the regulation. ${ }^{73}$

Legal relations between servants and lords were practically unchanged during the examined era. ${ }^{74}$ Compliance with the laws and regulations was uncertain. From November 1, 1907 two statutes regulated the legal relations of servants. The old one concerned inner (domestic) servants, while the new one related to agricultural (outside) workers. Consequently, the conditions of domestic servitude remained regulated by the Act of 1876 until the very end of the period. Unfortunately, available sources show that the issue was beyond the interest of local authorities.

The personal freedom of servants and their freedom of movement were limited. The use of physical and psychological violence against them was legal. Child labour was permissible from the age of 12. Some jobs were still unpaid: until 1907 forced labour was in use. The wives of servants were bound to do 16 days of free work in the manor annually. Therefore, with time the average wage of married male servants became significantly higher than single men's, and the wages of women were even lower. Based on data from 1905 , wages of servants had not been raised in the previous 50 years. ${ }^{75}$

The social welfare system was emerging under Act XVI of 1900 concerning the relief fund for agricultural workers and servants, but the benefits were only granted to the actual servants and workers; the widows of servants and their children remained without state support. There is a well-known case recorded by the local newspaper called "Somogy," according to which a servant (called György Szerelem) who had served for 39 years on the land of a Greek prince, Ypszilanti at Simongát, died while he was working, because a tree fell on him. He left five children, among them four were minors incapable of work. In spite of this, the directorate of the ducal estate of Vienna rejected his widow's request for support. ${ }^{76}$

\subsection{Sugar factory workers}

Employment became available in the sugar factory in 1894 . Women were employed in the factory only during the harvest season. Otherwise they worked as day-labourers, or servants. Due to the lack of appropriate vocational training they were mostly unskilled seasonal workers, which was reflected in their wages. Work for women became sig-

71 Somogy Megyei Levéltár IV.425. [Archives of Somogy IV.425.], Szabályrendeletek gyüjteménye 1. Vármegyei szabályrendeletek 1879-1943 [Collection of Ordinances 1. Ordinances of the County 1879-1943], vol. 220/2.609-1908.

72 Somogy Megyei Levéltár IV.425. [Archives of Somogy IV.425.], Szabályrendeletek gyüjteménye 1. [Collection of ordinances 1.], vol. 213/2034/1908.

73 Somogy Megyei Levéltár, Alispáni iratok 447/1930 [Archives of Somogy, Documents of the Deputylieutenant vol. 447/1930].

74 F. Szili, Cselédsors az uradalmas Somogyban a két világháború között [Life of Servants on the Estates of Somogy in the Interwar Period], Kaposvár 1976, p. 5.

75 K.T. Mérey, Adatok..., p. 6-15.

76 “Somogyi Hírlap", Kaposvár 1905. 
nificant in the factory only during the First World War. Then, from 1918 the number of female employees decreased again. ${ }^{77}$

At the turn of the $20^{\text {th }}$ century, the weekly wages of skilled workers were five times as much as those of day labourers. These wages were at the level of minimal subsistence anyway. ${ }^{78}$ In the interwar period, among 120 workers who worked in the factory, five were women. The situation was the same at the turn of the $20^{\text {th }}$ century. The average wages of women were less than $40 \%$ of men's in the same job. ${ }^{79}$ Working time was long and it afflicted especially mothers, as there weren't any state institutions for child care. ${ }^{80}$

\subsection{Female teachers}

The new concept of a public educational system that came into force in 1867 regulated the professional training of female teachers too, but it is clear that it did not take their work into consideration the first time. The legislature did not plan for their employment beyond the local public schools. ${ }^{81}$

It wasn't until 1879 that a woman was granted employment as an assistant teacher in Kaposvár. In this school-year only one more female teacher worked in the Jewish school in Kaposvár. Contemporaries held the opinion that female teachers' worth was equal to that of males, and together with the disappearance of prejudices concerning their employment, their presence was going to increase, especially in the higher classes for girls. ${ }^{82}$ According to statistics, in 1872 no female teachers were yet employed in public elementary schools in Kaposvár, but by 188112 female teachers already worked there, and in 1893 among 539 teachers, 31 were women. By the turn of the $20^{\text {th }}$ century (in 1899), the number of female teachers rose to $61 . .^{83}$

\subsection{Administrative jobs}

From 1870, more women were employed in post offices, in telegraph offices, and at train stations. ${ }^{84}$ According to actual public opinion, women were mostly suitable for teaching

77 F. Szili, I. Erdész, A Kaposvári Cukorgyár története 1894-1994 [The history of the Kaposvár Sugar Factory, 1894-1994], Kaposvár 1994, pp. 7-15.

78 A. Andrássy, A somogyi munkásmozgalom 1919-1944 között Elöadói segédanyag a történelmi szakosztály részére [The Working-class Movement in Somogy between 1919-1944. Auxiliary Materials of Lectures for History Section] [in:] F. Szili, Munkássors..., pp. 12-15.

79 F. Szili, Munkásság és a tisztviselők életkörülményei a Kaposvári Cukorgyárban és a béruradalomban [Living Conditions of Workers and Functionaries in the Kaposvár Sugar Factory and on Leased Estates in Somogy] [in:] idem, A cukorrépa termesztése Délkelet-Dunántúlon és a MIR Kaposvári Cukorgyára 1893-1948 [Sugar-beet Production in South-East Transdanubia and the Sugar Factory of the Joint-stock Company of the Agricultural Industry between 1893 and 1948], Kaposvár 1986, pp. 305-310.

80 L. Kővágó, I. Pintér, Munkássors-munkásgond 1919-1944 [Lives and Difficulties of Workers 1919-1944], Budapest 1962, p. 80.

81 K.N. Szegvári, $A z 1868 \ldots$, p. 67.

82 "Somogy" 1879, Vol. 37.

83 Királyi tanfelügyelöi jelentés [Report of the Royal School Inspector], "Somogy” 1893, Vol. XXIX, No. 11 , p. 1.

${ }^{84}$ A. Fábri, A nö és hivatása II..., p. 188. 
and medical professions. But, based on the Archives of Somogy county, women were not employed in local offices in Somogy in the examined era. This fact was connected with the lack of female education. The new educational system could achieve certain results after the turn of the $20^{\text {th }}$ century. Female employment in offices became common only in the interwar period.

\section{Final remarks}

In Hungary, the age of the Dualism is regarded as an age of modernisation. However, my research demonstrates many legal limits related to women's civil rights. Labour rights of women were closely connected with their educational rights. The lack of institutional education for women afflicted Somogy county, thus professional training for women - except for crafts and teachers' training - was totally lacking until 1891 . They were locked out of politics almost absolutely. Women also faced the problem of prostitution. The lack of protection for female- and child-labourers was a huge problem. Moreover, average wages of women were about half of men's even in 1917. ${ }^{85}$ Radical changes were needed in workplace safety just like in maternity care. ${ }^{86}$

The entire spectrum of women's movements felt the need for a change. Their efforts to improve the environment for women were the only answers to the given situation. The movements had numerous objectives: they wanted to highlight the unbearable conditions of women's lives; to draw society's attention to the problem of the white slave trade, to the need for criminal statutes to protect women's honour, to the social need for governmental measures for maternity benefits, and for improving women's possibilities for higher education and better work; and of course, they wanted to obtain the support of the public for all these goals.

By the 1860's this problem seemed almost impossible to solve, and it was closely connected with the absence of women's vocational training. So while the political struggle, especially the fight for voting rights, had never been an end in itself, it became the means of women's emancipation. Women stood up with the demand to participate in public life in order to take the very first steps towards legal and political equality, to obtain rights to education and work, and to secure acknowledgment of the value of maternity, child-care, and housework. They believed that if they could obtain results in these fields, the "woman question" would change. ${ }^{87}$

The struggles of the women's movements didn't touch on family law. Most of their claims referred to education, because women's status in family and traditional family models conformed to the cultural background of the actual society. The traditional Christian family model survived into the beginning of the $20^{\text {th }}$ century. Only later, after 1948, did the actions of the communist dictatorship succeed in liquidating this family

85 E. Bresztovszky, A magyar ipari munkásság életviszonyai a háború alatt [Living Conditions of Hungarian Industrial Workers during the World War], Huszadik Század [20 ${ }^{\text {th }}$ Century], Budapest 1916, pp. $23-24$.

86 K.N. Szegvári, Út a ..., pp. 116-121.

87 S. Zimmermann, Die bessere..., pp. 9-17. 
model, because the former model did not satisfy the radical demands of the women's struggle.

The family model with one breadwinner didn't fit Hungarian life of the 1950's. The actual propaganda also stressed that women had to work. In the second part of the $20^{\text {th }}$ century gender-determined social inequality diminished and a higher number of women received higher education. Politicians wanted to increase the female workforce rapidly for economic reasons. But in the general society, women still held a traditional role in the family.

\section{Bibliography}

Andrássy A., A somogyi munkásmozgalom 1919-1944 között. Elöadói segédanyag a történelmi szakosztály részére [The Working-class Movement in Somogy between 1919-1944. Auxiliary materials of lectures for history section] [in:] F. Szili, Munkássors - munkásgond Somogyban 1870-1945 [The Lives and Difficulties of Workers in Somogy 1870-1945], Kaposvár 1977.

Baráth F., Nevelés, tudomány, nöügy. A nök munkaköre [Education, Science, and Women's Affairs. Women's Jobs], Budapest 1872-1873.

Baross K., Magyarország földbirtokosai és bérlöi [Landowners and Tenants of Hungary] [in:] K.T. Mérey, Adatok a déldunántúli uradalmak gazdasági cselédségének életviszonyaihoz a századforduló idején [Data on the Living Conditions of Agricultural Servants of the Estates of South-Transdanubia at the Turn of the 20 $0^{\text {th }}$ Century], Pécs 1957.

Bassa E., Mit kell tudni a nömozgalmakról [What Must Be Known about the Hungarian Women's Movements], Budapest 1982.

Beniczky H.V., Felhívás a nökhöz [An Appeal to Women], Hon 1865.

Bresztovszky E., A magyar ipari munkásság életviszonyai a háború alatt [Living Conditions of Hungarian Industrial Workers during the World War], Huszadik Század [20 ${ }^{\text {th }}$ Century], Budapest 1916, pp. 23-24.

Csákányi (without firstname), Polgári leányiskola [Bourgeois Girls’ School] “Somogy” 1882, Vol. XVIII, Kaposvár, pp. 1-2.

Cserei F., A magyar és székely asszonyok törvénye [The Act Concerning Hungarian and the Székely <i.e. Magyar of Eastern Transylvania $>$ Women], Kolozsvár 1800.

Csiky K., A magyar nö jogai [Rights of Hungarian Women], "Nemzeti Nőnevelés" 1894, Budapest, p. 121.

Csorba J., Somogy vármegye ismertetése [Introduction to Somogy County], Pest 1857.

Fábri A., A nö és hivatása II. Szemelvények a magyarországi nőkérdés történetéböl 1866-1895 [The Woman and Her Profession II, Selected Passages from the History of the Hungarian Women's Question 1866-1895], Budapest 2006.

Finkey F., A magyar büntetőjog tankönyve [Coursebook of Hungarian Criminal Law] [in:] B. Mezey, Magyar jogtörténet [Hungarian Legal History], Budapest 1996.

Henig R., Henig S., Women and Political Power: Europe since 1945, London-New York 2000.

Herger E.Cs., A hozomány szerepe a magyar házassági vagyonjog fejlödésében [Dowry in the Development of the Hungarian Matrimonial Property Law], "Jogtudományi Közlöny" 2016, Vol. 4, pp. 193-203.

Herger E.Cs., A nö házassági vagyonjogi állása a német természetjogi kódexekben [The Status of Women in the Field of Marital Property Law in German Natural Law Codes], "Acta Universitatis Szegediensis: Acta Juridica et Politica” 2016, Vol. 1, Szeged (in press). 
Herger E.Cs., A növételtöl az állami anyakönyvvezetőig. A magyar házassági köteléki jog és az európai modellek [From the purchasing of Women to State Registration. Hungarian Marriage Law and the European Models], Budapest-Pécs 2006.

Illés, E.P., Az amerikai nők gyülése [Assembly of the American women] [in:] A. Fábri, A nö és hivatása II. Szemelvények a magyarországi nökérdés történetéböl 1866-1895 [The Woman and Her Profession II, Selected Passages from History of the Hungarian Women Question 1866-1895], Budapest 2006.

Jánossy G., A feminizmus Magyarországon [Feminism in Hungary], Szombathel 1911.

Kánya E., A háború és a nök [War and Women], "Családi Kör” 1866, p. 482.

Kelemen E., A népoktatás Somogyban a dualizmus kezdö éveiben (1867-1870) [Public Elementary Education in Somogy at the Very Beginning of Dualism (1867-1870)], "Somogy megye múltjából” 1973, Vol. 4, Kaposvár, pp. 205-206.

Kelemen E., A népoktatás Somogyban a kiegyezés előtti években [Public Elementary Education in Somogy before the Compromise of 1867], "Somogy megye múltjából" 1972, Vol. 3, pp. 137-168.

Kelemen E., Adatok a népoktatás Somogy megyei történetéhez (1881-1918) [Data on the History of Public Elementary Education in Somogy (1881-1918)], "Somogy megye múltjából. Levéltári évkönyv" 1980, Vol. 11, pp. 329-334.

Kelemen E., Kaposvári dualizmuskori közoktatástörténetének vázlata [Summary of the History of Public School Education of Kaposvár in the age of Dualism], "Somogy" 1973, Vol. 3, pp. 121-125.

Királyi tanfelügyelöi jelentés [Report of the Royal School Inspector], "Somogy” 1893, Vol. XXIX, p. 11.

Kovács J., Utazás a nöi egyenjogúság körül [Travelling around Emancipation] [in:] E. Bassa, Mit kell tudni a nömozgalmakról [What Must Be Known about the Hungarian Women's Movements], Budapest 1982.

Kővágó L., Pintér I., Munkássors-munkásgond 1919-1944 [The Lives and Difficulties of Workers 1919-1944], Budapest 1962.

Lehoczky Kollonai Cs., Amerikai sikertörténet - európai változások. A nöi egyenjogúság a nemzetközi gyakorlatban [American Success Story - European Changes. Women's Emancipation in International Practice] [in:] A hátrányos megkülönböztetés tilalmától a pozitív diszkriminációig. A jog lehetösége és korlátai [From Prohibition of Discrimination to Positive Discrimination. The Opportunities and Limits of the Law], Budapest 1998.

Máday A., A magyar nö jogai a múltban és a jelenben [Rights of the Hungarian Woman in the Past and in the Present], Budapest 1913.

Mérey K.T., A gazdasági és társadalmi viszonyok fejlödése Somogy megyében 1870-1918 [Progress of Economic and Social Relations in Somogy County 1870-1918], Kaposvár 1973.

Mérey K.T., A gyáripar Somogy megyében a két világháború között [Manufacturing Industry in Somogy in the Interwar Period], "Somogy megye múltjából. Levéltári évkönyv" 1972, Vol. 3, p. 227.

Mezei munkásság, házi cselédség [Agricultural Workers and Domestic Servants] [in:] Magyar Néprajz VIII. Társadalom, mek.niif.hu/02100/02152/html/08/98.html, pp. 1-6.

Miklóssy J., A budapesti prostitúció története [The History of Prostitution in Budapest], Budapest 1989.

Palasik M. (ed.), A nő és a politikum [The Woman and Politics], Budapest 2007.

Pálóczi Á.H., A magyar asszonyok prókátora a Budán összegyült rendekhez 1790 II [The representative of Hungarian Women to the Assembled Estates in Buda 1790 II], Budapest 1822.

Rácz G., A cselédtörvény javaslat bírálata [Critique of the Proposal on the Servants' Act] [in:] K.T. Mérey, Adatok a déldunántúli uradalmak gazdasági cselédségének életviszonyaihoz a századforduló idején [Data on the Living Conditions of Economic Servants in South Transdanubian Estates at the Turn of the $19^{\text {th }}$ and $20^{\text {th }}$ Century], Pécs 1957. 
Récsei B., A kéjelgésügy szabályozása Somogy vármegyében a dualizmus második felében [Regulation of Prostitution in Somogy County in the Second Part of the Dualism Era], "Somogy megye múltjából. Levéltári évkönyv" 2001, Vol. 32, p. 193.

Sápi V., A mezögazdasági cselédség magánjogi helyzete a dualizmus korában [Legal Status of Agricultural Workers in Private Law in the Age of Dualism] [in:] Jogtörténeti tanulmányok II. A dualizmus korának állam- és jogtörténeti kérdései, Budapest 1968, pp. 300-302.

Schreibel E., A prostitúció [Prostitution], Budapest 1917.

Somogy Megyei Levéltár IV.425. [Archives of Somogy IV.425.], Szabályrendeletek gyüjteménye 1. Vármegyei szabályrendeletek 1879-1943 [Collection of Ordinances 1. Ordinances of the County 1879-1943], vol. 220/2.609-1908.

Somogy Megyei Levéltár IV.425. [Archives of Somogy IV.425.], Szabályrendeletek gyüjteménye 1. [Collection of ordinances 1.], vol. 213/2034/1908.

Somogy Megyei Levéltár, Alispáni iratok 447/1930 [Archives of Somogy, Documents of the Deputy-lieutenant vol. 447/1930].

Szapor J., A magánszférából a politikai közéletbe: a női politizálás története a kezdetektöl 1945-ig [From the Private Sphere into the Political Public Life] [in:] M. Palasik (ed.), A nö és a politikum [The Woman and Politics], Budapest 2007.

Szegvári K.N., Az 1868. évi XXXVIII. tc jelentösége a nöképzés szempontjából [The Role of the Act XXXVIII of 1868 Concerning Women's Education] [in:] A. Csizmadia (ed.), Jogtörténeti tanulmányok I., Budapest 1966, pp. 55-72.

Szegvári K.N., Út a nők egyenjogúságához [The Way to Emancipation], Budapest 1981.

Szili F., Cselédsors az uradalmas Somogyban a két világháború között [Life of Servants on the Estates of Somogy in the Interwar Period], Kaposvár 1976.

Szili F., Munkásság és a tisztviselök életkörülményei a Kaposvári Cukorgyárban és a béruradalomban [Living Conditions of Workers and Functionaries in the Kaposvár Sugar Factory and on Leased Estates in Somogy] [in:] idem, A cukorrépa termesztése Délkelet-Dunántúlon és a MIR Kaposvári Cukorgyára 1893-1948 [Sugar-beet Production in South-East Transdanubia and the Sugar Factory of the Joint-stock Company of the Agricultural Industry between 1893 and 1948], Kaposvár 1986.

Szili F., Munkássors - munkásgond Somogyban 1870-1945 [The Lives and Difficulties of Workers in Somogy 1870-1945], Kaposvár 1977.

Szili F., Erdész I., A Kaposvári Cukorgyár története 1894-1994 [The History of the Kaposvár Sugar Factory, 1894-1994], Kaposvár 1994.

Teleki Gr.B., Elöbb reform, azután Nöemanzipátió [First Reform then Emancipation], "Életképek” 1848, Vol. 4, p. 593.

Tobak B., Nönevelésünk jelen állapota [The Actual Status of our Women's Education], "Somogy" 1869, Vol. V, p. 2.

Veres Beniczky H., Felhívás a nőkhöz [An Appeal to Women], "Hon”, Budapest 1865.

Zimmermann S., Die bessere Hälfte? Frauenbewegungen und Frauenbestrebungen in Ungarn der Habsburgermonarchie 1848-1918, Vienna-Budapest 1999. 


\section{Streszczenie}

\section{Tradycyjny model rodziny chrześcijańskiej oraz prawny status kobiet na Węgrzech (1867-1948)}

Rola kobiet w społeczeństwie jest związana $\mathrm{z}$ charakterem ich pozycji w rodzinie, $\mathrm{z}$ ich statusem ekonomicznym, wykształceniem, zatrudnieniem oraz prawami politycznymi i ich stosowaniem. W moich badaniach punktem wyjścia była druga połowa XIX wieku, gdy w wyniku reform obywatelskich z 1867 roku rozpoczął się rozwój praw kobiet. Celem moich badań, które w streszczeniu ukazuje niniejsze opracowanie, było przedstawienie statusu kobiet w obszarze prawa pracy. Starałam się zbadać, czy tradycyjny model rodziny przetrwał na Węgrzech w XIX wieku pomimo tego, że zarówno na rynku pracy, jak i z pewnością w życiu rodzinnym status kobiety uległ zmianie. W moich badaniach, skupiających się na studium statusu prawnego kobiet, skoncentrowałam się na typowym zatrudnieniu kobiet $\mathrm{w}$ rolnictwie. Opracowanie stanowi studium dokumentów na temat pracy kobiet dostępnych w Archiwum Komitetu Somogy. Jednocześnie niniejsze opracowanie umożliwia dokonanie przeglądu zarówno ówczesnej, jak i współczesnej literatury przedmiotu. Na Węgrzech zatrudnienie kobiet zaczęło wzrastać po 1890 roku. Ustawodawstwo austro-węgierskiej monarchii dualistycznej dobrze ilustruje status kobiet w obszarze prawa pracy tego czasu. Daje się zauważyć, że reformy w zakresie edukacji kobiet przyniosły owoce dopiero z końcem badanego okresu. Aż do tego momentu rola kobiet w społeczeństwie była determinowana modelem rodziny tradycyjnej, charakteryzującym się ograniczonym dostępem kobiet do edukacji, a szczególnie brakiem ich kształcenia zawodowego. W moim studium starałam się podkreślić, iż w okresie dualizmu pracownicze prawa kobiet były ściśle związane z ich prawami do edukacji. Niniejsze opracowanie potwierdza także, że ambicje ruchu kobiecego mające na celu poprawę sytuacji kobiet były jedynie odpowiedzią na zaistniałe uwarunkowania epoki.

Słowa klucze: prawa kobiet, emancypacja, edukacja, praca kobiet. 